Sobel, A. E., Shaw, J. H., Hanok, A. \& Nobel, S. (1960). F. dent. Res. 39, 462.

Sognnaes. R. F. (1948). J. Amer. dent. Ass. 37, 676 .

Sognnaes, R. F. \& Shaw, J. H. (1954). F. Nutr. 53, 195.

Speirs, R. L. (1963). F. dent. Res. 42, 1 103 (Abstract).

Stack, M. V. (1957). 7. dent. Res. 36, 325 .

Stack, M. V. \& Holloway, P. J. (1959). F. dent. Res. 38, 1223 (Abstract).

Steinman, R. R. (1962). Dentist, I, no. I.

Steinman, R. R. \& Haley, M. I. (1957a). F. dent. Res. 36, 532.

Steinman, R. R. \& Haley, M. I. (1957b). Proc. Soc. exp. Biol., N.Y., 94, 39 I.

Steinman, R. R. \& Haley, M. I. (1958), F. Dent. Child. 24, 211.

Steinman, R. R., Haley, M. I. \& O'Day, P. (1958). F. dent. Res. 37, 7 I9.

Steinman, R. R. \& Hardinge, M. G. (I958). $\mathscr{~}$. dent. Res. 37, 874 .

Sweeney, E. A., Shaw, J. H. \& Rubin, R. P. (r962). F. dent. Res. 4r, 866.

Ten Cate, A. R. (1962). Arch. oral Biol. 7, r.

Turner, N. C. (1960). F. Amer. dent. Ass. 61, 20.

Watson, B. D. \& Muhler, J. C. (1959). F. dent. Res. 38, 618.

Wills, J. H. \& Forbes, J. C. (1939). F. dent. Res. 18, 409.

\title{
Changes in the pattern of carbohydrate consumption in Britain
}

By J. P. Greaves and Dorothy F. Hollingsworth, Ministry of Agriculture, Fisheries and Food, Great Westminster House, Horseferry Road, London, SWI

Interest in carbohydrates, for long neglected by nutritionists, is reviving; this paper attempts to provide a factual assessment of carbohydrate consumption in Britain, as it exists today, and as it has changed over the past quarter-century. Estimates of consumption going back farther are necessarily less reliable, but general observations may be made with confidence. Thus it is well known that bread in former times occupied a much more prominent position in the diet than it does today: Lloyd (1936) has estimated that at the end of the eighteenth and early in the nineteenth century this one item represented $50 \%$ of the weekly expenditure on food in the labouring classes; today the proportion is about $7 \%$.

\section{Carbohydrate in the modern diet}

National Food Survey (NFS) records for 1961 (Ministry of Agriculture, Fisheries and Food, unpublished information) showed that for all the households surveyed, bread and flour provided on average just over a third of the total carbohydrate and potatoes $10 \%$, sugar and preserves together about a quarter, and milk 6\% (Table 1 ). These three groups respectively provide carbohydrate predominantly as starch, sucrose and lactose.

It must be remembered, however, that the NFS does not record consumption of chocolates, sweets, ice-cream (other than that consumed at meals) or soft drinks: expenditure on these items in 1962 averaged $6.5 \%$ of total household expenditure on food, excluding that spent on meals out (Ministry of Labour, 1963). Furthermore, the term consumption, as used in the Survey and in this paper, must not be confused with ingestion: it refers to the quantity of food entering the household which is available for human consumption, and though the nutrient conversion factors make allowance for the presence of inedible material such as potato peelings, losses of 
Table I. Provision of carbohydrate in the average diet

(National Food Survey, all households, I96I)

\begin{tabular}{lcc}
\multicolumn{1}{c}{ Foodstuff } & \multicolumn{2}{c}{$\begin{array}{c}\text { Carbohydrate } \\
\text { (monosaccharide) }\end{array}$} \\
\cline { 2 - 3 } Liquid milk & 20 & $\%$ of total \\
Sugar & 77 & $5 \cdot 7$ \\
Preserves & 8 & $22 \cdot 5$ \\
Potatoes & 36 & $2 \cdot 4$ \\
Other vegetables & 8 & $10 \cdot 4$ \\
Total fruit & I3 & $2 \cdot 3$ \\
Bread & 101 & $3 \cdot 8$ \\
Flour & $2 \mathrm{I}$ & $29 \cdot 4$ \\
Cakes and pastries & 15 & $6 \cdot \mathrm{I}$ \\
Biscuits & 16 & $4 \cdot 4$ \\
Other cereals & I7 & $4 \cdot 5$ \\
Other foods & II & $4 \cdot 9$ \\
Total, all foods : & 343 & $3 \cdot 5$
\end{tabular}

edible food are not considered, although when the adequacy of the diet is assessed, amongst further adjustments an arbitrary deduction of $10 \%$ is made (Ministry of Agriculture, Fisheries and Food: National Food Survey Committee, r $96_{3}$; Appendix A). A survey of London University students in 1962 (Ministry of Agriculture, Fisheries and Food, to be published) has provided evidence of one aspect of wastage. It was found that amongst those who took sugar in their tea the average quantity used was $10.7 \mathrm{~g}$, of which just over $10 \%(\mathrm{I} \cdot \mathrm{I} \mathrm{g}$ ) remained in the tea dregs. A survey conducted by the Tea Bureau in $195 \mathrm{I}$ showed that on average $75 \%$ of housewives take sugar in their tea, the proportion being lower in the richer classes and higher in the poorer.

\section{Changes in household consumption of carbohydrate since the prewar period}

During the war and immediate postwar years the NFS was restricted to households of the urban working-class. Selected results are compared in Table 2 with those for the appropriate classes surveyed before the war by Crawford \& Broadley (1938). In $195^{\circ}$ the Survey was extended to include households of all social classes, and average results are shown in Table 3 , together with prewar estimates. In i 960 slightly different tables of food composition were introduced, and carbohydrate was expressed in terms of monosaccharides, not starch, as previously (Ministry of Agriculture, Fisheries and Food: National Food Survey Committee, 1962; paragraphs $32-35$ ); values for carbohydrate given in Tables 2 and 3 for the years before 1960 have therefore been recalculated, and all values given in this paper are in terms of monosaccharides. The estimates of confectionery consumption shown in Table 3 are not obtained from survey data, but refer to national supplies at the retail level in the United Kingdom.

Bread consumption, which increased during the war to above the prewar level, declined sharply after I952, paralleled by a fall in potato consumption. Consumption of flour purchased as such is today about half that before the war, and is declining 
Table 2. Weekly consumption of chief carbohydrate-containing foods (oz/person, except for milk): urban working-class households: prewar and $1942-5^{\circ}$.

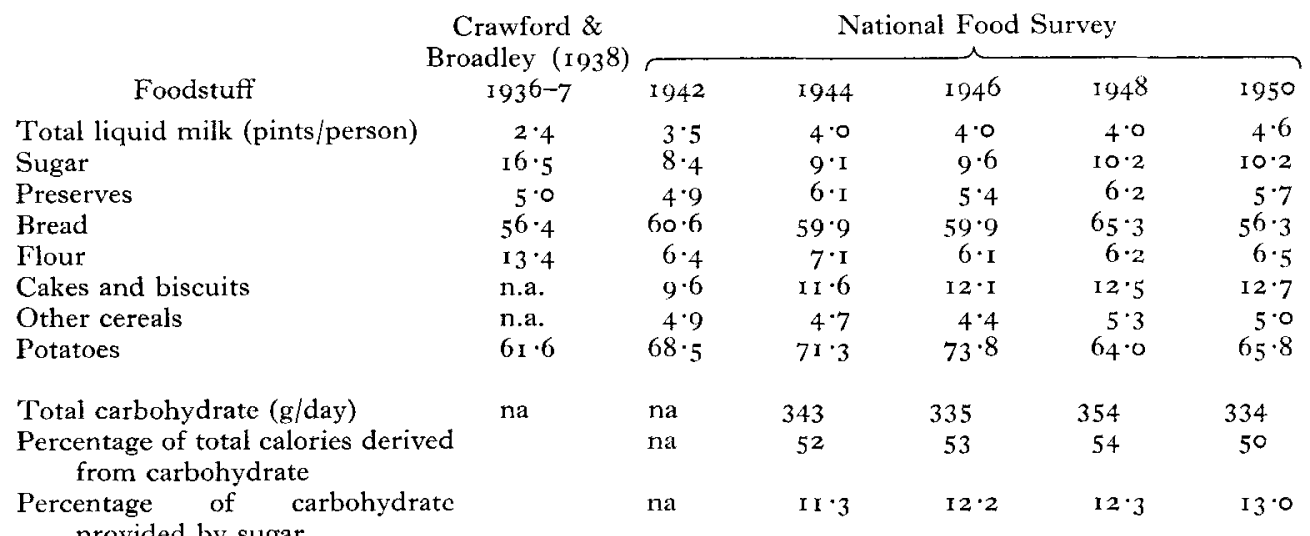

na, not available.

Table 3. Weekly consumption of chief carbohydrate-containing foods (oz/person, except for milk): all households: prewar and 1950-62

\begin{tabular}{|c|c|c|c|c|c|c|c|c|}
\hline \multirow[b]{2}{*}{ Foodstuff } & \multirow{2}{*}{$\begin{array}{c}\text { Crawford and } \\
\text { Broadley } \\
(1938) \\
1936-7\end{array}$} & \multicolumn{7}{|c|}{ National Food Survey } \\
\hline & & $195^{\circ}$ & 1952 & 1954 & I 956 & 1958 & I960 & 1962 \\
\hline $\begin{array}{l}\text { Total liquid milk (pints/ } \\
\text { person) }\end{array}$ & $2 \cdot 9$ & $4 \cdot 8$ & $4 \cdot 8$ & $4 \cdot 8$ & $4 \cdot 8$ & $4 \cdot 8$ & $4 \cdot 8$ & $5^{\circ} \circ$ \\
\hline Sugar & I $6 \cdot 7$ & $10 \cdot 1$ & I I $\cdot 0$ & $17 \cdot 0$ & $18 \cdot 0$ & I $8 \cdot 6$ & $17 \cdot 8$ & $18 \cdot 4$ \\
\hline Preserves & $5 \cdot 6$ & $6 \cdot 3$ & $6 \cdot I$ & $4 \cdot 2$ & $3 \cdot 7$ & $3 \cdot 5$ & $3 \cdot 2$ & $3 \cdot 3$ \\
\hline Bread & $54 \cdot 6$ & $57 \cdot 8$ & $6 I \cdot 5$ & $56 \cdot 3$ & $5 I \cdot I$ & $47 \cdot 2$ & $45^{\circ}+4$ & $43 \cdot 6$ \\
\hline Flour & I 3.9 & $7 \cdot 2$ & $8 \cdot 5$ & 8.8 & $7 \cdot 9$ & $7 \cdot 8$ & $6 \cdot 8$ & $6 \cdot 2$ \\
\hline Cakes and biscuits & na & 10.4 & $10 \cdot 2$ & 10.3 & 110 & II 4 & 12.0 & $12 \cdot 3$ \\
\hline Other cereals & na & $6 \cdot 3$ & $5 \cdot 8$ & $5^{\circ} 4$ & $5 \cdot 9$ & $6 \cdot I$ & $6 \cdot 4$ & $6 \cdot 6$ \\
\hline Potatoes & $62 \cdot 6$ & $64 \cdot 2$ & $65 \cdot 9$ & $63 \cdot 2$ & $58 \cdot 4$ & $55^{\circ} 4$ & $57 \cdot 2$ & $53 \cdot 6$ \\
\hline Total carbohydrate (g/day) & na & 344 & $35^{6}$ & 374 & 370 & 357 & 345 & 342 \\
\hline $\begin{array}{l}\text { Percentage of total calories } \\
\text { derived from carbo- } \\
\text { hydrate }\end{array}$ & & $5 \mathrm{I}$ & 53 & 52 & $5 \mathrm{I}$ & $5^{\circ}$ & 49 & 49 \\
\hline $\begin{array}{l}\text { Percentage of carbohydrate } \\
\text { provided by sugar }\end{array}$ & & $12 \cdot 5$ & $13 \cdot 2$ & $19 \cdot 4$ & $20 \cdot 7$ & $22 \cdot 2$ & $22 \cdot 0$ & $22 \cdot 9$ \\
\hline $\begin{array}{l}\text { Confectionery } \\
\text { (chocolate and sugar)* }\end{array}$ & $7 \cdot$ of & $4 \cdot 8$ & $5 \cdot 6$ & $8 \cdot 9$ & $8 \cdot 5$ & $8 \cdot 4$ & $8 \cdot 3$ & $8 \cdot 0$ \\
\hline
\end{tabular}

na, not available. $\quad{ }^{*}$ Retail level estimate. $\quad$ Prewar estimate.

steadily. Sugar rationing ended in 1953 , and consumption immediately rose to the prewar level, and beyond, though it now appears possibly to have reached a plateau. Confectionery consumption has steadily declined since I954, when it had risen sharply to over a quarter above the prewar level; the decline has been almost entirely in sweet confectionery, that of chocolate remaining at about $4 \mathrm{oz} /$ person weekly.

Carbohydrate now supplies just less than half the total calories in the average household diet; the highest proportion since 1944 was $54 \%$ in 1948 . Sugar, bought 
as such, now forms twice the proportion of carbohydrate consumed that it did in I 944 .

\section{Influence of family size}

The findings of the prewar Carnegie Survey on working-class families have been compared with appropriate results of the NFS for the period $1955^{-8}$ (Baines, Hollingsworth \& Leitch, I963); selected data are shown in Table 4. Purchases of

Table 4. Weekly household consumption (oz/person, except for milk) in working-class families, I $937^{-9}$ and $1955^{-8}$

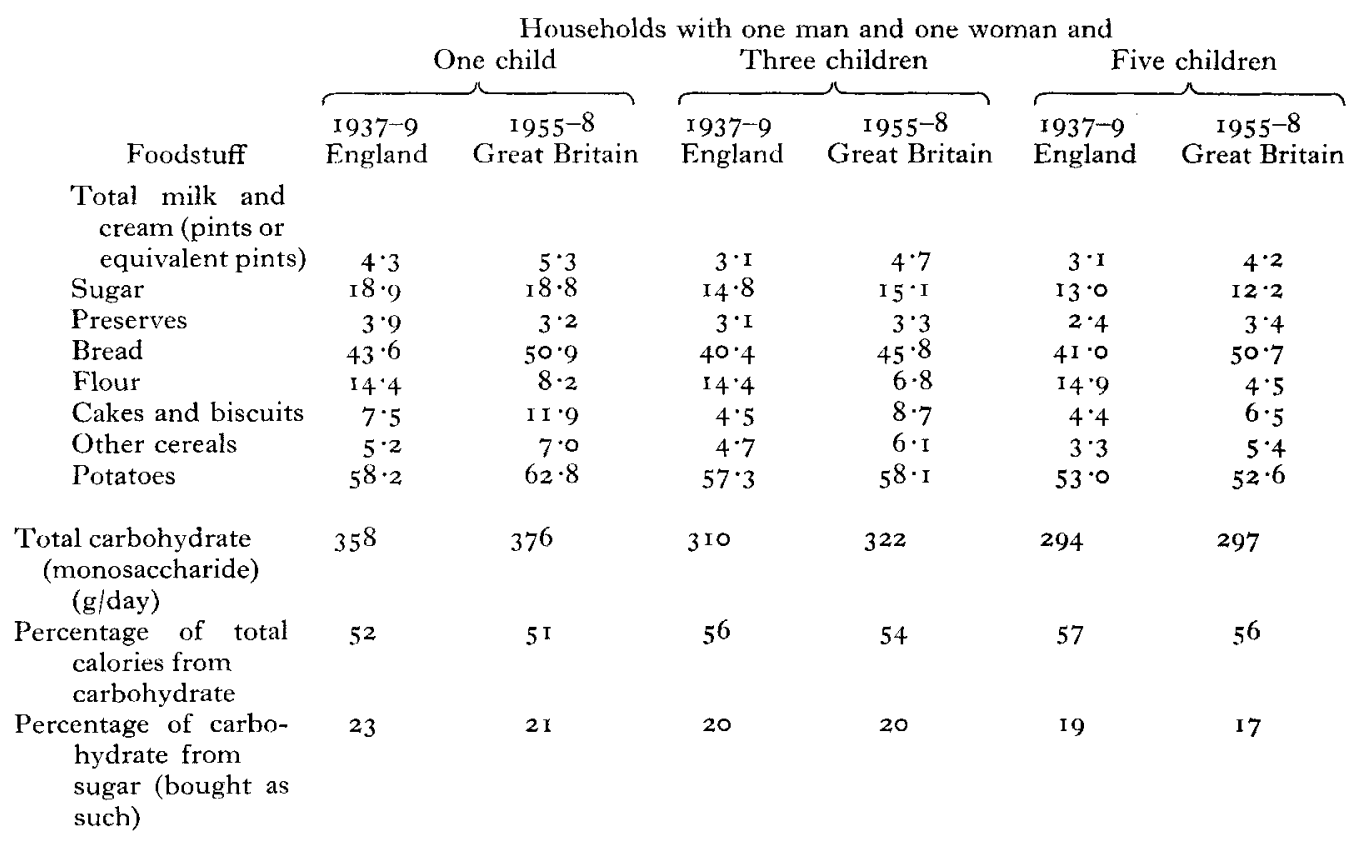

bread were greater after than before the war, but the difference was offset by reduced purchases of flour. Consumption of cakes and biscuits, 'other' cereals, and total milk was greater after the war. The effect of an additional child on the food consumption of the household was investigated by fitting linear regressions to total consumption data: it was estimated that the additional consumption of sugar attributable to each additional child in the family was, in the prewar survey, $6.8 \mathrm{oz} /$ week, equivalent to I $2.9 \%$ of the estimated young couple's consumption; in the postwar period it was I I $\circ \mathrm{oz} /$ week, equivalent to $24 \cdot 3 \%$ of the couple's consumption. The percentage increment in household consumption per child increased for potatoes from $27 \%$ to $38 \%$; it also increased for preserves and all cereal foods other than bread, for which it decreased from $80 \%$ to $49 \%$ (Baines et al. 1963 ).

The effect of family size on the consumption of potatoes, as revealed by the NFS, is what would be expected for a food which is a fairly cheap, but not the cheapest, source of energy. As the size of the family increases and income per head declines, the average consumption (per person) of potatoes at first falls because the presence 
of children reduces average energy requirements per head, then rises because of increased dependence on the cheaper foods, and in the largest families may fall again at a time when even potatoes are considered relatively expensive compared with bread. This upward turn from the second to the third child occurred consistently in the Survey up to 1956 , frequently with a slight downward turn for the fourth child. Since that date the minimum consumption of potatoes has shifted from the advent of the second to that of the third child (when the minimum consumption of bread usually occurs), though the earlier pattern was repeated in 1959. Further details of potato consumption are given by Wadsworth \& McKenzie (I963).

\section{Influence of social class}

NFS records show that, though households in the lower social classes derive a greater proportion of their calorie needs from carbohydrate than do those in the higher, the differences are slight. For example, in 1962 households consisting of childless couples under 55 years of age in Class A obtained $46 \%$ of their calories in this way, and similar households in Classes C \& D I obtained $48 \%$; both groups of households obtained $24 \%$ of their total carbohydrate from sugar, bought as such. (Social classes in the Survey are defined in terms of income ranges of heads of households, which are reviewed each year (Ministry of Agriculture, Fisheries and Food: National Food Survey Committee, I963; Appendix A).)

Since 1955 the consumption of sugar in households of both richer and poorer classes has changed little, and has not differed appreciably between the classes; the contribution of sugar to carbohydrate consumption has tended to increase slightly, but again at similar rates in the different classes. However, substantial changes have occurred since before the war. Crawford \& Broadley's (r938) survey between October 1936 and March 1937, though not entirely comparable with the NFS, may be used to estimate general trends in class differences. Table 5 shows that the very considerable narrowing in the gap between the classes for liquid milk consumption is due to the consumption of the poorest classes having more than doubled. The consumption of sugar in these classes has risen by about twice as much as it has in the richest, thus almost obliterating the class differences that existed before the war.

Table 5. Changes in consumption of carbohydrate sources by social classes

Difference between richest and
poorest groups as percentage of
mean consumption
$1936-7^{*}$
Foodstuff

Percentage change in consump-
tion of richest and poorest
groups between $1936-7$ and
$1962-3$

Richest Poorest

Liquid milk

Sugar

Potatoes (purchased)

Bread

Flour

$\begin{array}{rr}121 & 30 \\ 16 & 4 \\ -\quad 3 & -\quad 5 \\ -26 & -32 \\ 11 & -\quad 2\end{array}$

$\begin{array}{ll}+25 & +209 \\ +15 & +29 \\ -25 & -15 \\ -35 & -28 \\ -41 & -34\end{array}$

*Crawford and Broadley (1938) survey, October 1936-March 1937. Classes (AA+A) and D. †National Food Survey, October 1962 - March 1963. Classes $A_{1}$ and $D$ (all). 
The richest classes have reduced their consumption of bread, flour and potatoes more than have the poorest, so that for bread and potatoes the gap has widened, and the poorer classes still consume relatively more than the richer.

\section{Total food supplies}

Trends in supplies of the main sources of carbohydrate are shown in Table 6. Before the First World War the United Kingdom included the whole of Ireland, and thus the drop in potato consumption recorded between the prewar and postwar

Table 6. Trends in carbohydrate supplies in the United Kingdom

\begin{tabular}{|c|c|c|c|c|c|c|c|c|}
\hline \multirow[b]{2}{*}{ Foodstuff (lb/person year) } & \multirow[t]{2}{*}{1880} & \multirow[t]{2}{*}{ I $909-13$} & \multirow[t]{2}{*}{ r $924-8$} & \multirow[t]{2}{*}{$1934-8$} & \multirow[t]{2}{*}{ r $94 \mathrm{r}$} & \multirow[t]{2}{*}{1947} & \multicolumn{2}{|c|}{$\begin{array}{c}\text { I962 } \\
\text { r953 (provisional) }\end{array}$} \\
\hline & & & & & & & & \\
\hline Liquid milk & 213 & 219 & 217 & 217 & 265 & $3 \circ 3$ & 330 & 326 \\
\hline Sugar* & 64 & 80 & 89 & 105 & 69 & 84 & 102 & 115 \\
\hline Potatoes & 296 & 243 & 230 & r9o & 188 & 286 & 245 & 208 \\
\hline Wheat flour & 280 & $2 I I$ & 108 & 195 & 237 & 225 & 193 & 162 \\
\hline Other cereals & na & 26 & 16 & 16 & 20 & 17 & 16 & 16 \\
\hline \multicolumn{9}{|l|}{ Calorie distribution (\%) } \\
\hline Total carbohydrate & 66 & 56 & 54 & $5 \mathrm{I}$ & 53 & 55 & $5 \mathrm{I}$ & 48 \\
\hline Liquid milk & 6 & 6 & 6 & 6 & 7 & 8 & 8 & 8 \\
\hline Sugar & I I & I 4 & 15 & I 7 & 12 & 14 & I6 & I 8 \\
\hline Potatoes & 8 & 7 & 6 & 4 & 5 & 7 & 6 & 5 \\
\hline Cereals & 48 & 37 & 33 & 30 & 40 & 36 & 30 & 24 \\
\hline \multicolumn{9}{|c|}{ Carbohydrate distribution $(\%)$} \\
\hline Liquid milk & 3 & 3 & 3 & 3 & 4 & 4 & 5 & 5 \\
\hline Sugar & 17 & 25 & 28 & 33 & 22 & 25 & $3 r$ & 37 \\
\hline Potatoes & I I & II & 10 & 8 & 8 & I I & 10 & 9 \\
\hline Cereals & 64 & $5^{6}$ & $5 \mathrm{I}$ & 50 & 62 & 53 & 48 & 43 \\
\hline
\end{tabular}

*Less the sugar used in brewing and distilling, but including that in manufactured foods.

periods may be partly accounted for by the exclusion of Eire from the second assessment (Ministry of Health: Advisory Committee on Nutrition, 1937). Figures for these two periods have been based on original data (Royal Society Committee, I9I7; Flux, 1930), though the 'cottage' production of potatoes was thought to be overestimated, and later estimates of potato consumption have been preferred (Ministry of Health: Advisory Committee on Nutrition, 1937). Flux's (1930) estimates of consumption of the proximate principles have been accepted, subject to modifications due to the changed estimate of potato consumption, and also to the adoption of modern carbohydrate conversion factors for vegetables (particularly potatoes) and fruit. The early conversion factors gave very high values, being based presumably on the estimation of total carbohydrate by difference, with virtually no allowance for waste. Calorie values were revised by using the factors 4,9 and $4 \mathrm{kcal} / \mathrm{g}$ for protein, fat, and carbohydrate (mixed), respectively. The r 880 estimate was based on Lloyd's (1953) interpretation of a British Association for the Advancement of Science (1882) report, and on comparisons with data for 1909-13. These early data have neither the same foundation, nor the same authority, as those for 1934-8 and $23(2) 3$ 
those given subsequently (Ministry of Agriculture, Fisheries and Food, 1962, I 963), which form a self-consistent series. Even so the prewar estimate of potato consumption ( $190 \mathrm{lb} /$ person yearly) is regarded as probably an underestimate (Ministry of Agriculture, Fisheries and Food: National Food Survey Committee, I $96_{3}$; 'Table 2 , footnote d.).

Nevertheless the changes in the patterns of the calorie and carbohydrate distributions shown in Table 6 are believed to bear some approximation to the facts. The single years selected include a period of wartime restriction (r94I), of postwar shortage (1947), and of the end of food controls (1953).

Lloyd (1936) on the basis of contemporary reports estimated the consumption of wheat flour and of sugar in 1835 , respectively, as about 360 and $20 \mathrm{lb}$ yearly per person, indicating that in the last century and a half flour consumption has rather more than halved, while sugar consumption has increased sixfold. The highest recorded figure for gross sugar consumption, including that used for brewing and distilling, was $122 \mathrm{lb} /$ person yearly, in $\mathrm{I} 96 \mathrm{I}$, representing a $12 \%$ increase on the prewar gross estimate (Ministry of Agriculture, Fisheries and Food, 1963). The abrupt rise in consumption after about the mid-nineteenth century (Lyle, 1950) was rendered possible by the great fall in price (Lloyd, i 936) consequent on improved technology. Sugar in all its forms (excluding that used in brewing and distilling) now provides $18 \%$ of our total calorie supply and $37 \%$ of our total carbohydrate - twice as much as at the turn of the century.

Estimates of carbohydrate consumption in terms of the monosaccharides of which it is composed, which of necessity must be rough approximations, suggest that total daily consumption was about $490 \mathrm{~g}$ monosaccharides/person in $\mathrm{I} 880$, made up of $43^{\circ} \mathrm{g}$ glucose and about $5^{\circ} \mathrm{g}$ fructose, and $4 \mathrm{I} \mathrm{I} \mathrm{g}$ in $\mathrm{I} 962$, consisting of approximately $320 \mathrm{~g}$ glucose and $80 \mathrm{~g}$ fructose. Carbohydrate consumed as starch decreased from about $380 \mathrm{~g}$ to $230 \mathrm{~g}$, the starch : sucrose ratio thus decreasing from $4 \frac{1}{2}$ to $1 \frac{1}{2}$ approximately.

The trends that have occurred in the United Kingdom this century are very similar to those reported for the United States (Leverton, I963). There, carbohydrate supplied $57 \%$ of the calories in 1910 , and $47 \%$ in 1962 ; corresponding figures for the UK are $56 \%$ and $48 \%$ (Table 6 ). In I9Io, cereals and potatoes provided $44 \%$ of total calories in the US and also in the UK; in 1962 the figures are $24 \%$ and $29 \%$, the decrease not being so great in the UK partly because potato consumption, which was halved in the US over this period, did not change so greatly in this country. The contribution of sugar and syrups to the US calorie supply rose from $I I \%$ in 1910 to $I 6 \%$ in 1962 ; for the UK the figures are $13 \%$ and $18 \%$.

\section{REFERENCES}

Baines, A. H. J., Hollingsworth, D. F. \& Leitch, I. (1963). Nutr. Abstr. Rev. 33, 653 .

British Association for the Advancement of Science ( 1882 ). Report of Committee on Appropriation of Wages.

Crawford, W. \& Broadley, H. (1938). The People's Food. London: Heinemann.

Flux, A. W. (1930). F. R. statist. Soc. 93, 538 .

Leverton, R. M. (I963). Nutritional Trends and the Consumer's Food. USDA Agricultural Research Service. 4ist Annual Agricultural Outlook Conference, Washington, DC. 
Lloyd, E. M. H. (1936). F. agric. Econ. Soc, 4, 89.

Lloyd, E. M. H. (1953). F. agric. Econ. Soc. ro, 174.

Lyle, P. (I950). F. R. statist. Soc. Ser. A, Ir3, 53 I.

Ministry of Agriculture, Fisheries and Food (r962). Bd Trade $\mathcal{F}_{\text {. }} \mathbf{1 8}_{\mathbf{3}}$, i.

Ministry of Agriculture, Fisheries and Food (r963). Bd Trade 7. r85, 296.

Ministry of Agriculture, Fisheries and Food: National Food Survey Committee (1962). Domestic Food Consumption and Expenditure: 1960. London: H. M. Stationery Office.

Ministry of Agriculture, Fisheries and Food: National Food Survey Committee ( I963). Domestic Food Consumption and Expenditure: 1961. London: H. M. Stationery Office.

Ministry of Health: Advisory Committee on Nutrition (1937). First Report. London: H. M. Stationery Office.

Ministry of Labour (1963). Family Expenditure Survey: 1962. London: H.M. Stationery Office.

Royal Society Committee (1917). The Food Supply of the United Kingdom. Cd. 842 r. London: H.M. Stationery Office.

Wadsworth, G. R. \& McKenzie, J. C. (1963). Nuir. Abstr. Rev. 33, 327.

\section{Carbohydrate consumption and diabetes}

\section{By Joan B. Walker, Diabetic Department, Leicester Royal Infirmary}

While research into carbohydrate metabolism and the action of insulin is increasing, clinicians continue to treat diabetes by regulating the intake of carbohydrate. It is surprising that we achieve the present degree of success because one is bound to accept a multifactorial theory of aetiology of the disease. What part carbohydrate consumption may play must be correlated with such factors as sex, age, heredity, physique, hormonal adjustment, social status, energy expenditure, stress, and finally dietary habits. The increasing amount of information that is being gathered in each of these fields of study leaves us somewhat bewildered, yet we must be reaching the state of full saturation when crystallization of thought should take place.

Correction of diet is the basic therapy for all diabetics and how successful it will be depends not only on the intelligence and co-operation of the patient, but also on the experience and skilful art of the teacher.

\section{Historical note}

In retrospect, it is of interest that in the history of diabetes, essential 'management' has usually preceded investigation. Three hundred years ago, Willis advocated a reduction in carbohydrate intake as a means of bringing about an 'undernutrition cure'. Rollo ( 1796 ; quoted by Duncan, I95I) restricted his diabetic patients' diet to animal food and green vegetables. Bouchardat ( 1883 ) noted that one in twenty of the wealthy, well-fed professional class in Paris in 1875 would be found to be glycosuric. He prescribed a small diet and occasional days of fasting. This $5 \%$ of glycosuria compares with the recent figure of $4.8 \%$ that we found in 1962 in the well-fed village community of Ibstock.

It was Allen (1914) who systematized undernutrition therapy for diabetes in the belief that diabetes was a disorder of total metabolism and not of carbohydrate alone'. The late Elliot P. Joslin (Joslin, Root, White \& Marble, 1959) in Boston and Russell Wilder ( $1957^{-8}$ ) of the Mayo Clinic used Allen's diet extensively up to the 